\title{
Neotropical Planorbid Snails with Apertural Lamellae. I. Biomphalaria helophila (Orbigny, 1835)
}

\author{
W Lobato Paraense
}

\author{
Departamento de Malacologia, Instituto Oswaldo Cruz, Avenida Brasil 4365, 21045-900 \\ Rio de Janeiro, RJ, Brasil
}

\begin{abstract}
A definition of Biomphalaria helophila (Orbigny, 1835) is presented, based on examination of the shell and reproductive system of topotypic specimens and extended to a number of samples from other localities. The following nominal species and subspecies, collected from type localities, proved junior synonyms of B. helophila: Planorbis albicans Pfeiffer, 1839; Planorbis dentatus Gould, 1844; Planorbis dentiferus $C B$ Adams, 1845; Planorbis dentiferus edentatus $C B$ Adams, 1851; Planorbis dentiens Morelet, 1849; Planorbula dentiens edentula Fischer \& Crosse, 1880; Planorbis stagnicola Morelet, 1851; and Tropicorbis shimeki FC Baker, 1945.

B. helophila was also identified in samples from Costa Rica, Guatemala, Haiti, Dominican Republic, Puerto Rico and Barbados.
\end{abstract}

Key words: Neotropical Planorbidae - synonymy - Biomphalaria helophila - Planorbis albicans -

Planorbis dentatus - Planorbis dentiferus - Planorbis dentiens - Planorbis stagnicola -

Tropicorbis shimeki

Several species of pulmonate snails of the family Planorbidae develop a set of usually six inward projections from the shell, called lamellae, deeply situated in the apertural region. In classical treatises of malacology (e.g. FC Baker 1945) lamellate species are placed in separate genera or subgenera: Segmentina Fleming, 1817, Planorbula Haldeman, 1840, Haldemanina Dahl, 1905, Odontogyrorbis Lörenthey, 1906, and Obstructio Haas, 1939. So far no adequate explanation has been given to the presence of apertural lamellae in those snails. A common observation is the association of the latter with temporary bodies of water - that is, those which contain water at certain times or seasons and become dry at others. Consequently their populations are adapted to life in some quiescent condition (Paraense \& Deslandes 1956, Paraense 1957). In the Neotropics this group is represented by about 20 nominal species, of which Planorbis helophilus Orbigny, 1835 bears the oldest available name.

Examination of samples I have collected from type localities of Neotropical planorbids point to the identity of some nominal species with $P$. helophilus - now called Biomphalaria helophila (Orbigny, 1835) - as shown below.

Although there is no record of natural infection of B. helophila with Schistosoma mansoni, it

CNPq Research Fellow. Fax: 55-21-280.5840

Received 9 August 1995

Accepted 19 October 1995 proved susceptible in laboratory experiments by Richards (1963), using specimens from Puerto Rico under the name Tropicorbis albicans.

Voucher specimens of the studied material are deposited in the malacological collection of Instituto Oswaldo Cruz (CMIOC).

\section{ORBIGNY'S DESCRIPTION OF BIOMPHALARIA HELOPHILA}

The original description reads as follows (Orbigny $1835: 27$, no figure; type locality Callao, Peru):

10. P. helophilus, Nob. - Testa depressa, tenui, laevigata, albida; superne plana; centro concavo, subtus plano, umbilicato; quatuor anfractibus; suturis profundis; apertura obliqua, semi-lunari. - Alt. 11/2 millim., ampl. 5 millim. - Habit. Provincia Limacensi (republica Peruviana).

Another description with figures appeared later (Orbigny $1837:$ 349-350):

PLANORBE HÉLOPHILE, Planorbis helophilus, d'Orb.

Mollusques, pl. XLV, fig. 13-16.

Planorbis helophilus, d'Orb., Syn., Mag.de zool. (1835), p. 27, no 10.

P. testâ depressâ, crassâ, laevigatâ, albidâ, supernè subtùsque concavâ; anfractibus tribus rotundis, convexis; suturâ profundâ; aperturâ gibbâ, obliquâ; labro crasso. Diam. 5 millim.; alt. 11/2 millim.

Coquille: Deprimée, épaisse, lisse; spire presque plane, mais très-concave au centre, en dessus et en dessous, composée de trois tours arrondis, tous convexes, séparés par une suture profonde; bouche transverse, souvent difforme, un peu comprimée en dessous, à bords épais. 
Couleur: Gris blanchâtre, uniforme.

Le Planorbe hélophile a encore beaucoup de rapports de forme avec le Planorbe pélerin: les tours de spire en sont de même arrondis et peu déprimés; mais il est toujours de moitié plus petit, lisse; son enroulement sur un plan horizontal est constamment et également concave, au centre, des deux côtés; sa bouche épaissie et difforme; enfin, il n'a jamais que trois tours de spire.

Nous avons rencontré cette espèce dans les marais qui avoisinent, au nord, le port du Callao, sur la côte du Pérou; elle y est peu commune et se tient principalement dans les marais, près des lieux rocailleux.

In the Natural History Museum, London, there are 11 syntypes of $B$. helophila, the largest one 5.5 $\mathrm{mm}$ in diameter (Fig. 1A). Seven specimens, 4-5 $\mathrm{mm}$, show a set of apertural lamellae, a character overlooked by Orbigny; one of them is shown in Fig. 1B. The larger shells have really four whorls, as stated by Orbigny in 1835 (see his Figs 13-14 of 1837), not "never more than three" (Orbigny 1837). Moreover, the whorls are actually subangular - as depicted in mentioned Figs 13-14 - rather than "rounded".

\section{A REDESCRIPTION OF SPECIMENS FROM CALLAO}

A study of $B$. helophila, based on material collected at Fundo SanAndrés, about $1 \mathrm{~km}$ west of Trujillo, Peru, and $500 \mathrm{~km}$ north of Callao (CMIOC-783), was published by Paraense and Ibañez (1964). A brief redescription of specimens collected by the author from a marsh at Callao in April 1965 (CMIOC-1071) is presented below.

The largest shell (Fig. 2A) is $5.5 \mathrm{~mm}$ in diameter, $2 \mathrm{~mm}$ in width at the aperture $(1.5 \mathrm{~mm}$ at the beginning of the outer whorl), and has 4.5 whorls. Each side shows a central depression, funnel-like on the right, broadly concave on the left. The
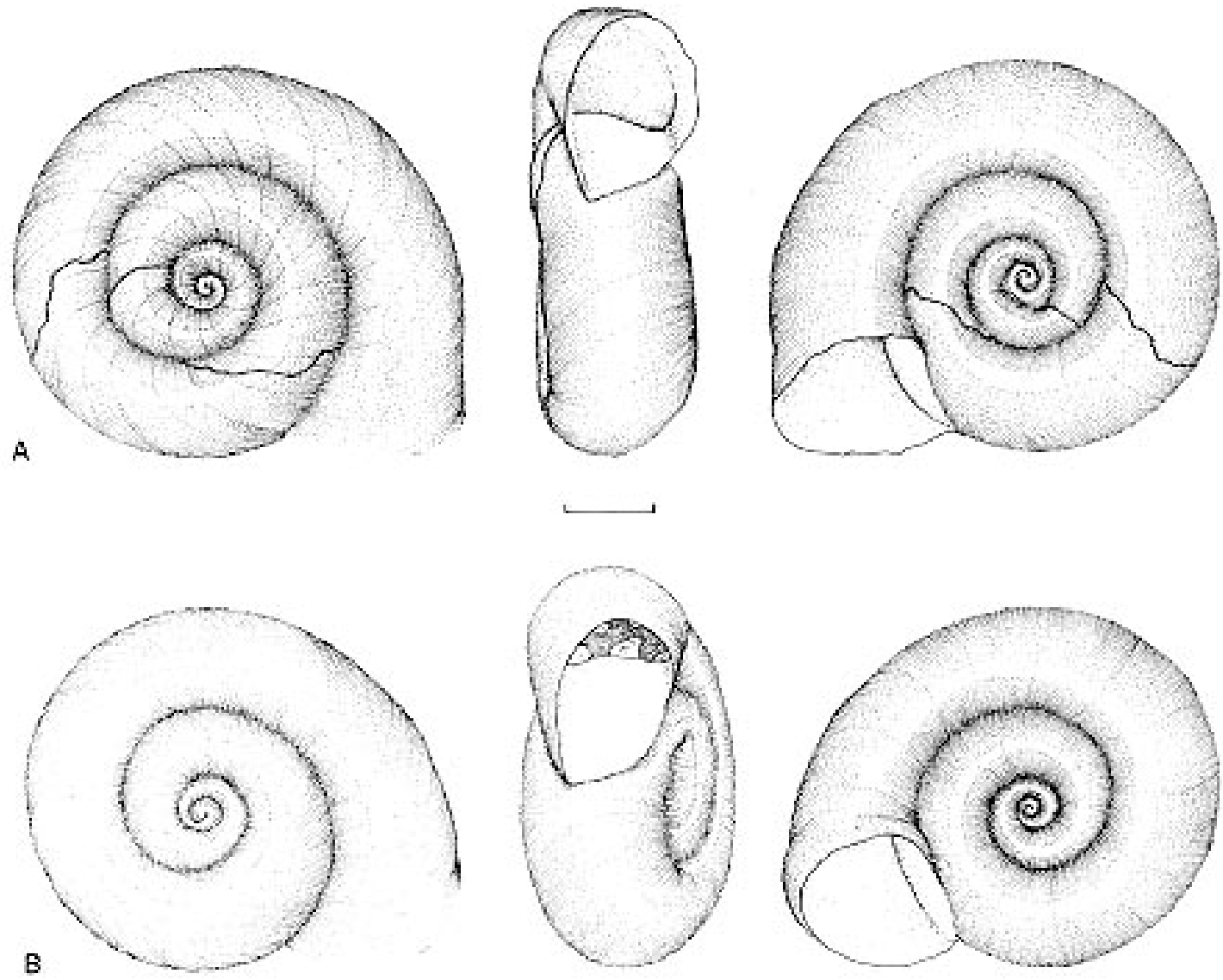

J.E $P=200$

Biomphalaria helophila from Callao, Peru - Syntypes, Natural History Museum, London - Fig. 1A: shell of largest specimen (non-lamellate). Fig. 1B: lamellate specimen. Bar $=1 \mathrm{~mm}$. 
whorls are obtusely angular on both sides, more prominently on the left, and separated by a deep suture. The innermost whorls are visible on both sides, more plainly on the left. The periphery is rounded and tends to the right. The aperture is oblique and egg-shaped; its right wall is from a little convex to flattened, and its left wall and periphery are rounded. In mature specimens the aperture is usually deflected, sometimes sharply, to the left. The lips are usually thin, but may be thickened by an inner callous deposit. Three out of 18 shells 4 to $5 \mathrm{~mm}$ in diameter show a set of six apertural lamellae, of which two are parietal and four palatal (Fig. 2B).

The cephalopedal mass is diffusely brownishgray. The pigmentation is deeper on the velum, grows lighter toward the foot margins and is lacking on the tentacles and their lappets. White granules are scattered on the foot, head, tentacles and mantle collar, gathering into a granular fleck in
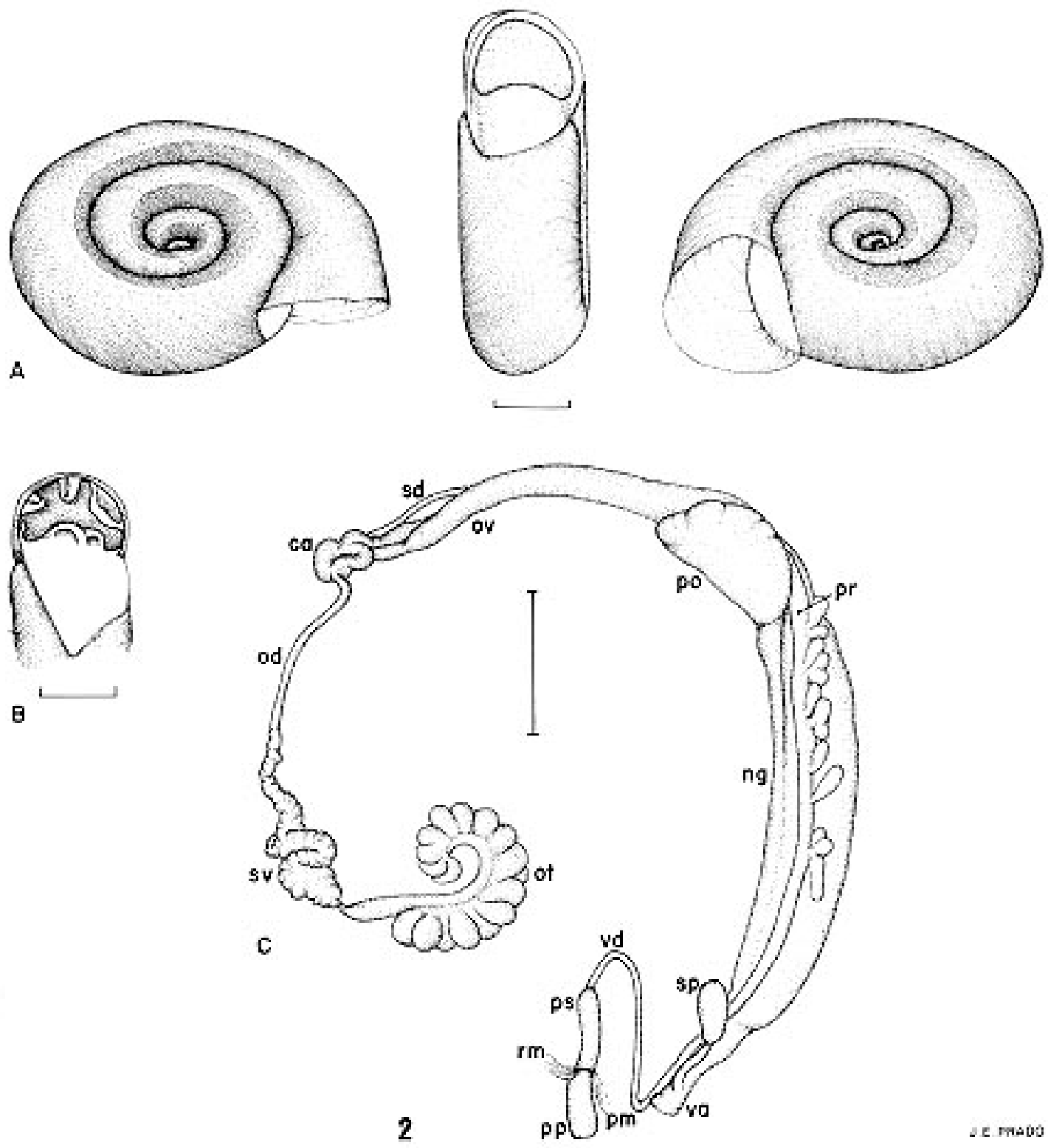

ve mavo

Biomphalaria helophila from Callao, Peru - Topotypes (CMIOC-1071) - Fig. 2A: shell. Fig. 2B: lamellate specimen. Fig. 2C: reproductive system $\mathrm{ca}=$ carrefour, $\mathrm{ng}=$ nidamental gland, od $=$ distal segment of ovispermiduct, ot $=$ ovotestis, ov $=$ oviduct, $\mathrm{pm}=$ protractor muscle of penial complex, $\mathrm{po}=$ pouch of oviduct, $\mathrm{pp}=$ prepuce, $\mathrm{pr}=$ prostate, $\mathrm{ps}=$ penis sheath, $\mathrm{rm}=$ retractor muscle of penial complex, $\mathrm{sd}=$ spermiduct, $\mathrm{sp}=$ spermatheca, $\mathrm{sv}=$ seminal vesicle, $\mathrm{va}=$ vagina, $\mathrm{vd}=$ vas deferens. $\mathrm{Bar}=1 \mathrm{~mm}$. 
front of each eye and on each lappet. The roof of the pulmonary cavity is blotched with black. There is no renal ridge.

The reproductive system is shown in Fig. 2C. The ovotestis has about 20-30 pear-shaped, predominantly unbranched, occasionally bifurcate diverticula. The seminal vesicle is beset with numerous small knobs corresponding to parietal diverticula. The oviduct, the oviducal pouch, the nidamental gland and the uterus show no special features. The vagina is short and smooth-walled. The spermatheca varies in shape with the amount of its contents, showing a usually obovate body nearly as long as the duct or a little longer. The spermiduct gives off a series of 5-14 prostatic diverticula, mainly bi- or trifurcate, less frequently unbranched or arborescent. The penis sheath is about the same length to twice as long as the prepuce (range 1.04-2.08, mean 1.35 $\pm 0.24 \mathrm{SD}, \mathrm{N}=$ $20)$. The prepuce is only a little wider than the penis sheath. As usual with Biomphalaria, there are two main extrinsic muscles inserted into the junction of the penis sheath with the prepuce: a retractor arising from the columellar muscle and a protractor connected with the head wall. The cephalic portion of the female duct (from the middle of the oviducal pouch to the vaginal opening) is more than twice as long as the penial complex (penis sheath plus prepuce) (range 2.74-4.57, mean $3.63 \pm 0.46$ $\mathrm{SD}, \mathrm{N}=20$ ).

\section{PLANORBIS ALBICANS PFEIFFER, 1839}

Original description (Pfeiffer 1839: 354, no figure; type locality Cuba):

43. Planorbis albicans Pfr. - Testa orbiculari, utrinque umbilicata, solidula, albicante vel pallide fulvicante, anfract. 3 teretibus; labro subincrassato albo; apertura subovata. - Diam. $2 \frac{1}{2} 2$ [about $5.3 \mathrm{~mm}$ ], alt. 1'" [about 2 $\mathrm{mm}]$. - Dem Pl. albus (hispidus) am nachsten verwandt.

In the above description no reference is made to apertural lamellae, but it applies well to Orbigny's non-lamellate syntypes of $P$. helophilus. Moreover, $P$. albicans was described as a lamellaproducing species by Clessin (1884).

My specimens from Cuba (Paraense \& Deslandes 1962) were collected, in December 1956, at Laguna Somorostro (Havana, CMIOC258 ) and Laguna La Canoa (Candelaria, province of Pinar del Río, CMIOC-261). In shell characters (Fig. 3A) they are similar to the Peruvian specimens, 2 out of 11 of them showing apertural lamellae (Fig. 3B). In the reproductive system (Fig. 3C) they also agree with the Callao specimens, showing 8-16 prostatic diverticula, penis sheath/prepuce ratio 1.20-2.38, cephalic portion of female duct/ penial complex ratio 2.75-3.81.

\section{PLANORBIS DENTATUS GOULD, 1844}

Original description (Gould 1844 : 496, Pl. 24, Fig. 14; type locality San Jorge, Cuba):

Testâ discoideâ, solidulâ, pallidè corneâ, utroque umbilicatâ; anfr. 3 leviter striatis, supra et infra subcarinatis; suturâ profundâ; aperturâ sublunatâ; labro intus callo albo incrassato; fauce dentibus sex, abditis, armatâ.

Shell discoidal, rather solid, pale horn-colored, about equally umbilicated on both sides; whorls three or a little more, feebly striated and slightly carinated above and below; aperture embracing about half the penultimate whorl, rounded lunate, the lip supported within a riblike, white callus; at a distance of about one fourth of a volution within the throat are six unequal, lamellar teeth, two on the inner, one on the upper, and three on the outer aspect of the throat; their place may be readily seen through the shell; diameter, 3/20 inch [about $4 \mathrm{~mm}$ ]; height, 1/20 inch [about $1.3 \mathrm{~mm}$ ]. Found in a small lagoon at San Jorge [a sugar plantation on Sagua La Grande river].

Commenting on his $P$. dentatus, Gould says: "It may possibly be the species characterized by Pfeiffer under the name of $P$. albicans, but if so, he has failed to notice its most interesting character [the apertural lamellae], I therefore venture to propose for it the name $P$. dentatus."

Really, Gould's figure shows a shell very similar to that of albicans, only differing from the latter in being a little smaller.

For many years the only dentate planorbid recorded in Cuba (Aguayo 1938: 228) was $P$. albicans. Afterwards this same author (Aguayo 1961 : 98) referred to Gould's P. dentatus as the dentata form of albicans. The identity of albicans with helophila was demonstrated on anatomical grounds by Paraense and Ibañez (1964). Two other dentate species occurring in Cuba are Biomphalaria obstructa and B. schrammi, as referred to by Yong et al. (1984), but they are quite distinct, in shell and anatomy, from helophila.

\section{PLANORBIS DENTIFERUS CB ADAMS, 1845}

Original description (Adams $1845:$ 17, no figure; type locality Jamaica):

PLANORBIS DENTIFERUS. P. dentato, Gould, affinis; t.anf. 4, ultimo quam penultimo, haud multò latiore; sed $P$. dentatus ultimum maximum habet, (v.fig. Gouldianam); dentium labialium dextrâ bifidâ, magnâ; dentibus sicut in specie Gouldianâ dispositis.

$P$. dentiferus Adams and P. dentatus Gould are not sibling species, as stated above; they are actually identical and synonyms of $B$. helophila. The specimen shown in Fig. 4 was collected in May 1967 from a pond at Dahlford, St. Elizabeth parish (CMIOC-1605), and has two sets of lamellae. Ad- 
A
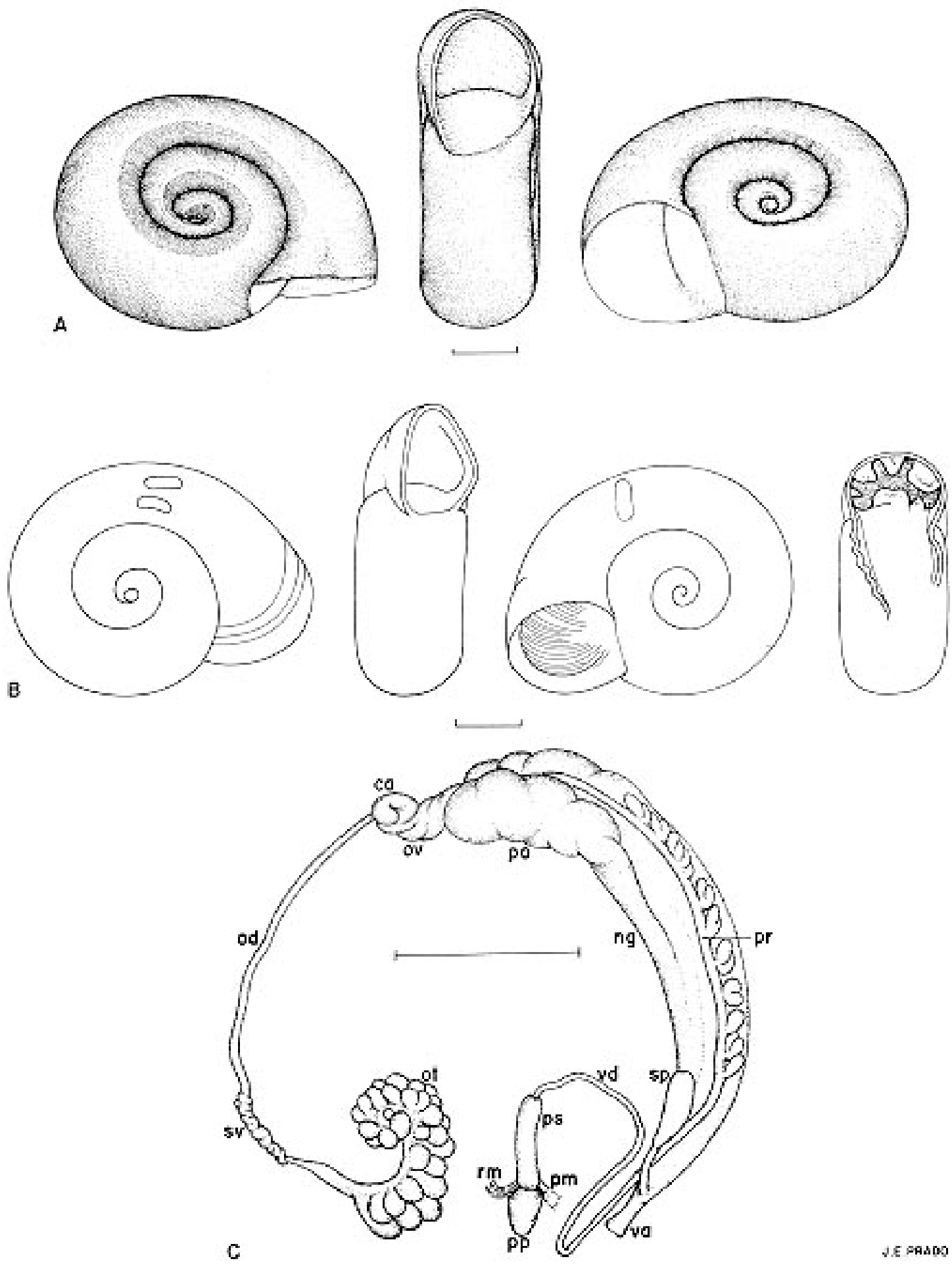

3

JE คคADO

Biomphalaria helophila from Havana, Cuba (=Planorbis albicans Pfeiffer, 1839) - Topotypes (CMIOC-258) - Fig. 3A: shell. Fig. 3B: lamellate specimen. Fig. 3C: reproductive system. Abbreviations as in Fig. 2C. Bar $=1 \mathrm{~mm}$. 
ditional samples were collected from small ponds and slow-running shallow creeks at Middle Quarters (St. Elizabeth, CMIOC-1614), Toms River, Castleton (St. Andrew, CMIOC-1594), Hectors River (Portland, CMIOC-1589), Qwaw Hill and White Horses (St. Thomas, CMIOC-1587, 1582), and Ferry River, Caymanas Bay (St. Catherine, CMIOC-1600).

In all those samples both lamellate and unarmed shells are present, totaling 70 and 74 specimens, respectively. This fact had been observed by Adams (1851 : 132), who wrote:

Of Planorbis dentiferus Ad., (Proc.Bost.Soc. Jan. 1,
1845 ,) a variety occurs, which is destitute of teeth! After a careful examination of many specimens, I am unable to find any other differences constantly associated with this peculiarity. Many of the toothless shells are more compressed obliquely just below the periphery, than the type, but the same is true of some of the shells in which the teeth are well developed. It is not a local variety, both kinds occurring together at Hatfield, in Westmoreland. The variety may be designated by the name EDENTATUS."

\section{PLANORBIS DENTIENS MORELET, 1849}

Original description (Morelet $1849: 18$, no figure; type locality Belize, British Honduras):
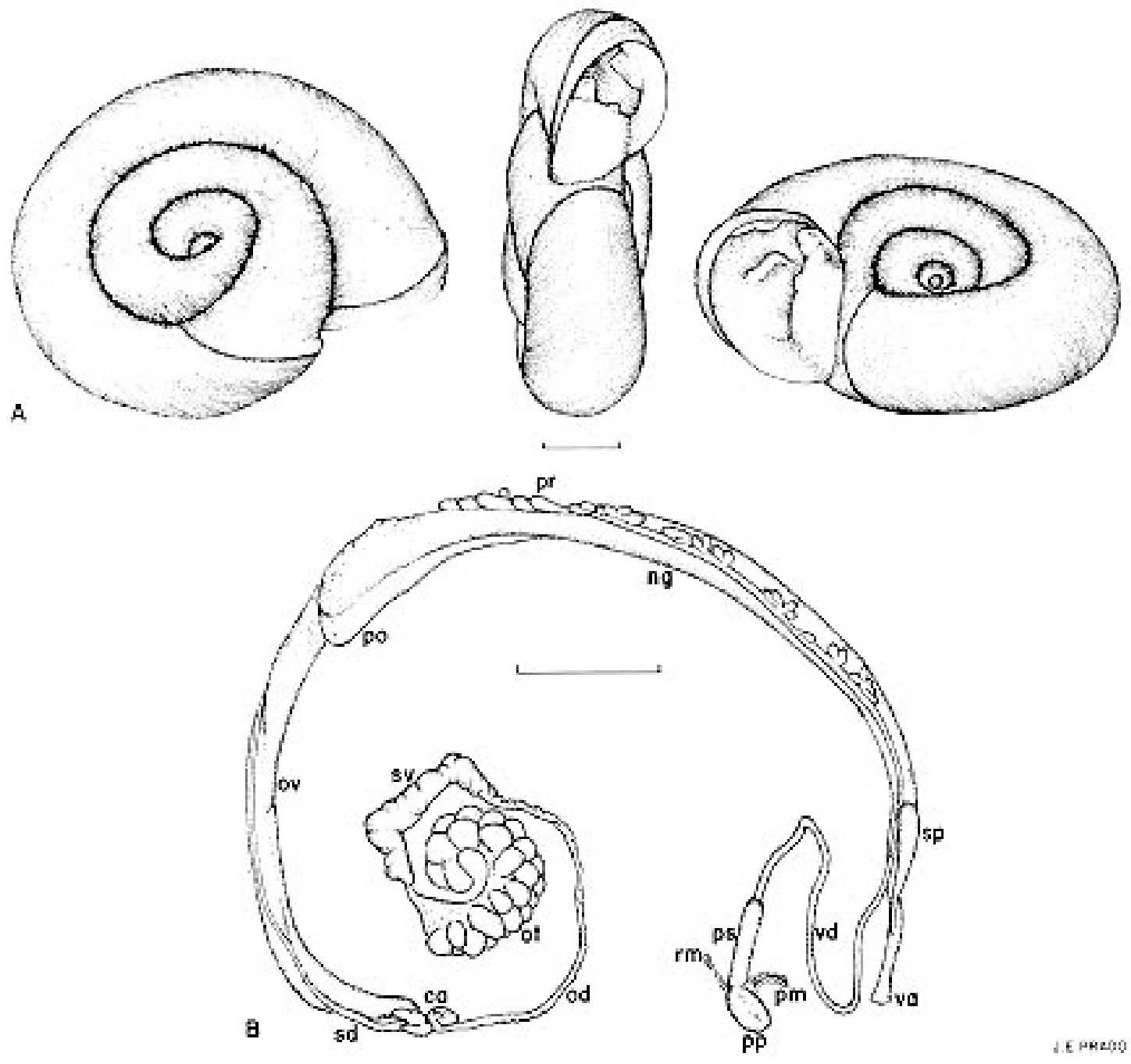

d. EREOP

Biomphalaria helophila from Dahlford, St. Elizabeth parish, Jamaica (=Planorbis dentiferus CB Adams, 1845) - Topotype (CMIOC-1605) - Fig. 4A: shell with two sets of lamellae: the first set was formed in a shell of $3.5 \mathrm{~mm}$ diameter, when the snail stopped growing, in all probability as an adjustment to environmental severities; then it resumed growth, leaving behind a ridge (rest mark, or growth ring) indicative of growth stop; a second set of lamellae was formed at a size of $5.5 \mathrm{~mm}$, followed by a second rest mark and further growth resumption. Fig. 4B: reproductive system. Abbreviations as in Fig. $2 \mathrm{C}$. Bar $=1 \mathrm{~mm}$. 

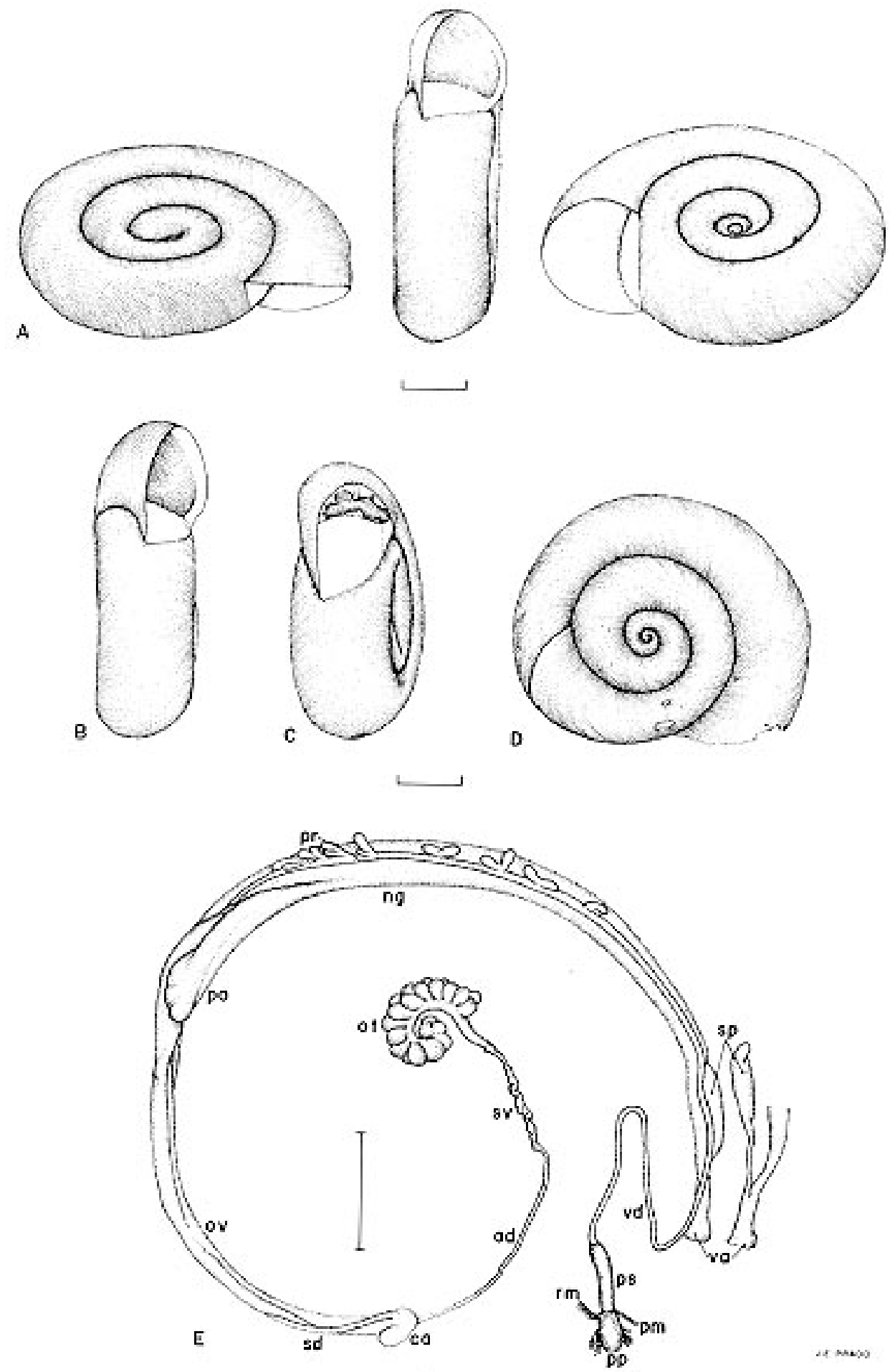

5

Biomphalaria helophila from Belize, British Honduras (=Planorbis dentiens Morelet, 1849) - Topotypes (CMIOC-2293) - Figs 5A, B: non-lamellate specimens, 5B with strongly deflected aperture. Fig 5C: lamellae at apertural region. Fig. 5D: lamellae farther back in former apertural region (delimited by growth ring indicative of growth stop); after resumed growth no lamellae were produced in newly formed portion. Fig. 5E: reproductive system. Abbreviations as in Fig. $2 \mathrm{C}$. Bar $=1 \mathrm{~mm}$. 
40. P. dentiens. - T. discoidea, solidula, levis, superne subtiliter perforata, inferne vix excavata; anfr. 7 depressi, ultimo obsolete angulato; apertura oblique lunaris, intus lamellis 4 in ventre anfractus ultimi et dentibus 2 in pariete aperturali oppositis, una punctiformi, altera obliqua, compressa, utraque albida, profunde coarctata; peristoma simplex. - Diam 5. Altit. 2. - H. paludosa circa Belize, in littore Hondurasano.

In July 1976 I collected 38 specimens, answering to the above description, from a little pool beside the road from Belize city to the international airport (Air Port Mile 8, CMIOC-2293). The largest one is $6 \mathrm{~mm}$ in diameter and has 4.75 whorls (not 7, as recorded by Morelet, which for a Neotropical planorbid $5 \mathrm{~mm}$ in diameter must be a misprint). Four of those specimens, measuring 4.0 to $5.5 \mathrm{~mm}$, are lamellate. As shown in Fig. 5, $P$. dentiens is indistinguishable from B. helophila.

The non-lamellate form of this snail was named Planorbula dentiens var. edentula by Fischer and Crosse (1880 : 80-81, Pl. 34, Figs 6-6c).

\section{PLANORBIS STAGNICOLA MORELET, 1851}

Original description (Morelet 1851 : 14-15, no figure; type locality Bahia Honda, Cuba):

113. Pl. stagnicola. - T. depressa, supra umbilicata, subtus vix concava, subtiliter striata; anfr. 5 superne semiteretes, subtus angulati, ultimo basi subdilatato. Apertura obliqua, semirotunda; perist. simplex, marginibus callo contiguis. - Diam. 6. - Altit. 2. - H. paludosa littoris Cubensis, ad portum Bahia-Honda.

In the above description no mention is made of apertural lamellae.

The largest of five syntypes in the Natural History Museum, London, is $6 \mathrm{~mm}$ in diameter by 2 $\mathrm{mm}$ in width (1.5 at the beginning of the outer whorl), and has 4.5 whorls. A specimen, $5.5 \mathrm{~mm}$ in diameter, has a well-marked growth ring followed by $1 \mathrm{~mm}$ of newly formed aperture, and a set of lamellae, not outwardly apparent (Fig. 6A). Another specimen, with strongly deflected aperture, has deeply situated lamellae visible through the shell wall (Fig. 6B). All these shells are identical with that of $B$. helophila, differing from those of B. obstructa and B. schrammi, the other lamellate species recognized in Cuba.

\section{TROPICORBIS SHIMEKI FC BAKER, 1945}

Original description (Baker 1945 : 218-219, Pl. 134, Figs 12-14, 28; type locality Ometepe, Nicaragua):

Shell solid, small, of three and one-half whorls. Upper surface showing three and one-half whorls which are subangulate above, sutures very deep. Lower surface showing three and one-half whorls which are subangulate in the middle, sutures very deep. Whorls rounded on the periphery. Apical whorls sunken on both surfaces. Whorl slightly deflected at aperture. Aperture lunately rounded, outer lip thick with callus. A callus on parietal wall connecting the extremities of the outer lip. Sculpture of coarse growth lines with fine spiral lines. Apertural lamellae six, those of sigmoid form extremely short and thick, only slightly more than half the length of those found in obstructus.

Shell Greater Lesser Aperture Aperture

Height Diameter Diameter Height Diameter

$\begin{array}{llllll}1.5 & 4.0 & 3.2 & 1.1 & 1.0 & \text { Holotype } \\ 1.6 & 3.8 & 3.1 & 1.1 & 1.1 & \text { Paratype } \\ 1.5 & 3.4 & 2.8 & 1.1 & 1.0 & \text { Paratype }\end{array}$

Type Locality. Ometope [misprint for Ometepe], Nicaragua.

Type Material. Collected by B. Shimek in 1893. Four specimens deposited in United States National Museum, Accession no. 534290. The holotype is shown on plate

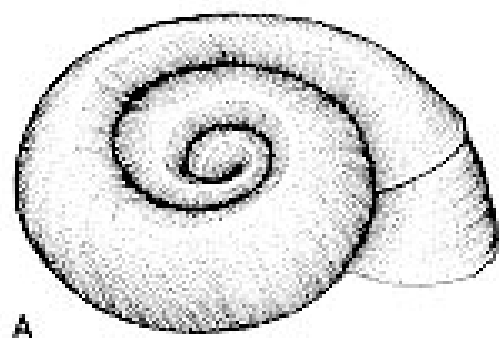

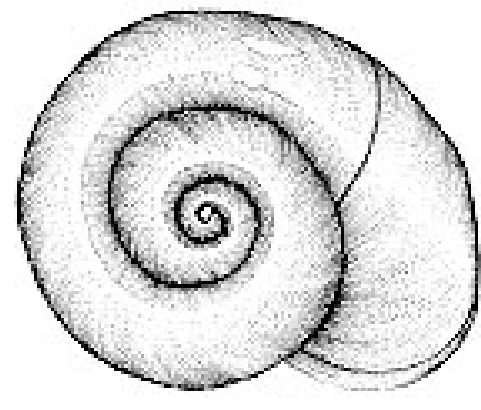

$\mathrm{B}$

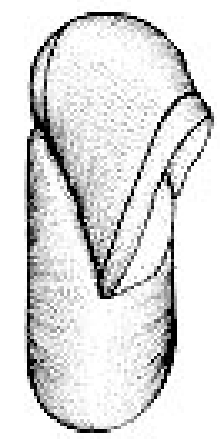

J.E $=$ HEXO

Biomphalaria helophila from Bahia Honda, Cuba (=Planorbis stagnicola Morelet, 1851) - Syntypes, Natural History Museum, London - Fig. 6A: shell with outwardly unapparent lamellae. Fig. 6B: lamellate shell with strongly deflected aperture. Bar $=1$ $\mathrm{mm}$. 
134 as fig. 12; figs. 13, 14 are paratypes.

Tropicorbis shimeki resembles albicans but is smaller, has a greater axial height, and has subcarinate whorls. The parietal lamellae are distinctly shorter and thicker than in other forms of the genus. T. shimeki is smaller than declivis and its axial height is greater; it also has deeper sutures than are found in declivis.

Additional representatives of $T$. shimeki were collected by Orcutt in Coatzocoales [misprint for Coatzacoalcos],
Mexico (United States National Museum, Accession no. 219696).

This species is named in honor of Professor B. Shimek.

In August 1976 I collected a sample of this snail from a pond at Moyogalpa (on the Ometepe island), consisting of 12 lamellate and 5 non-lamellate specimens (CMIOC-2328), 3.5-5.0 mm in diameter. Fig. 7 shows that they do not differ from B. helophila.
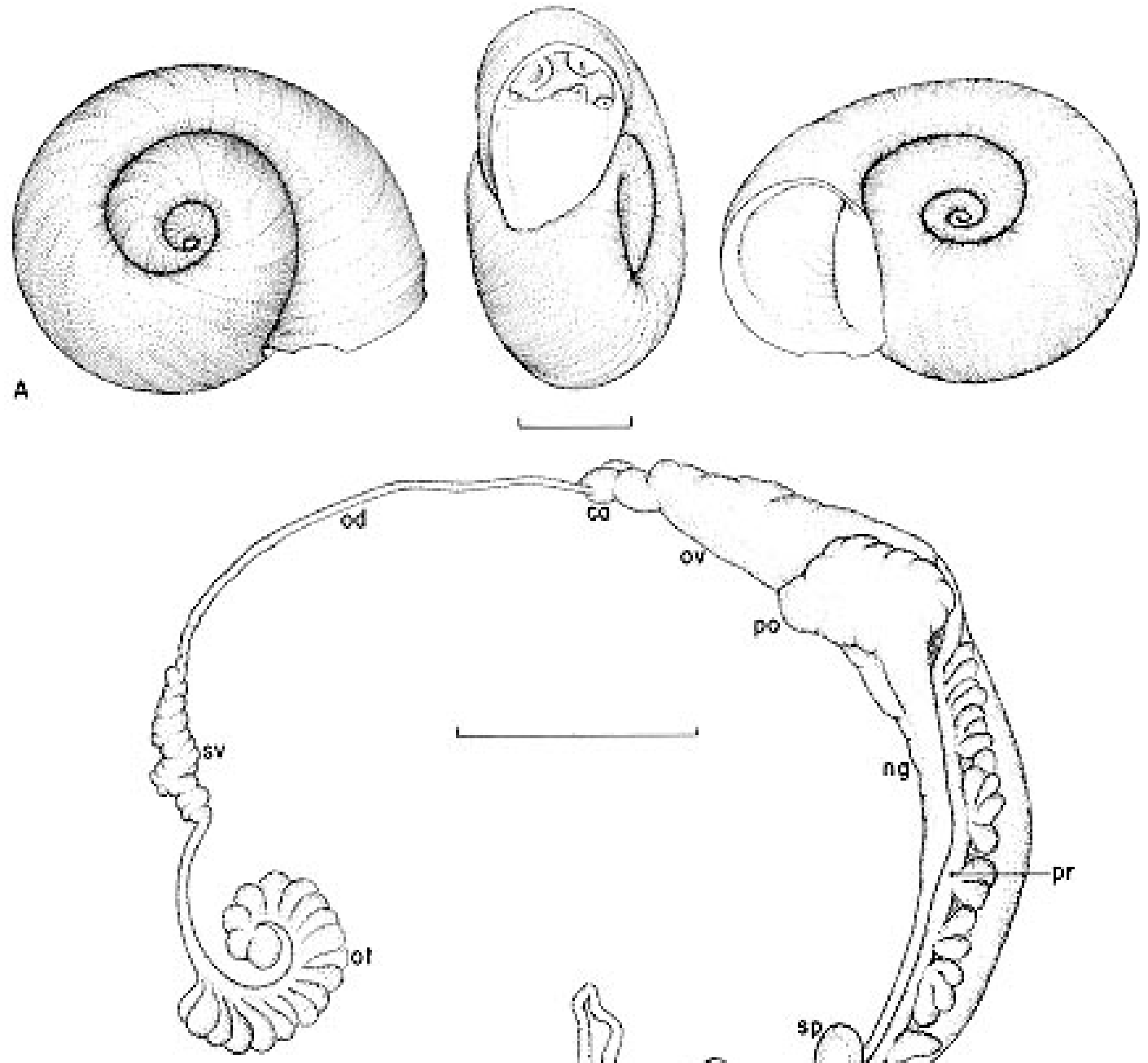

B

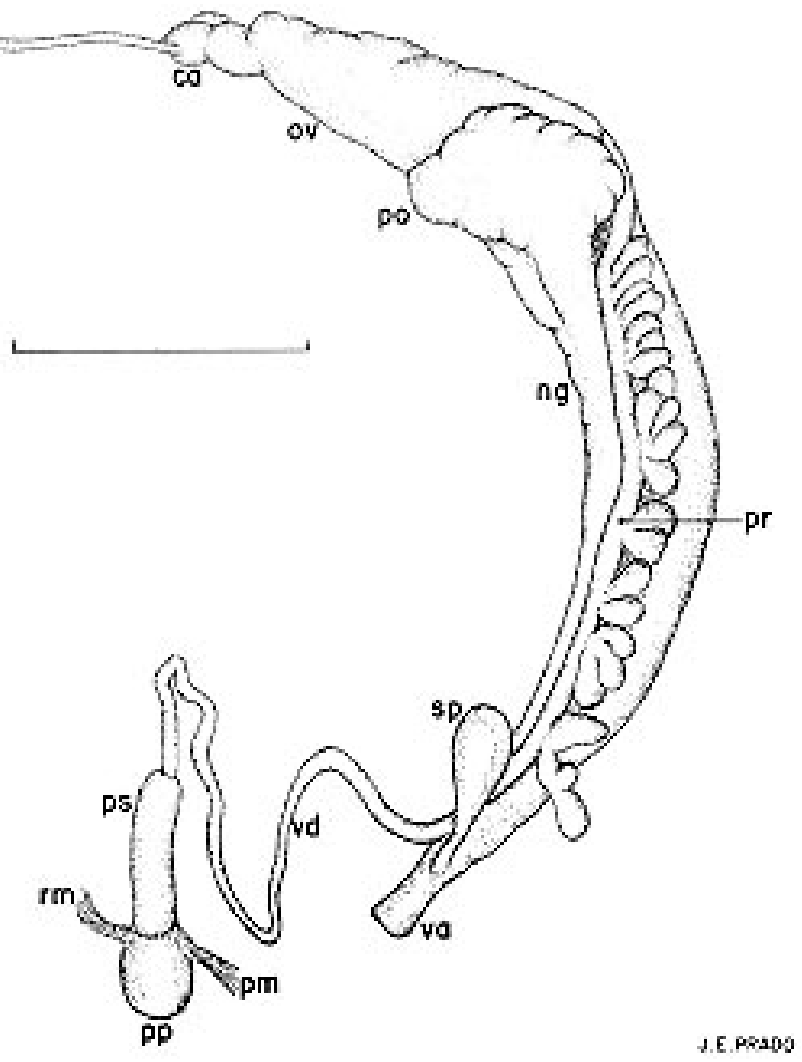


As seen above, T. shimeki is stated by Baker to differ from albicans (=helophila) in having subcarinate whorls. However, his figures of albicans (Baker 1945, Pl. 134, Figs 4-6) show clearly subcarinate shells. Other alleged differences should be assigned to individual variation.

\section{ADDITIONAL LOCALITIES FOR BIOMPHALARIA HELOPHILA}

Besides the above-mentioned type localities, I collected samples of $B$. helophila at the following places:

- Costa Rica: Catalina, Guanacaste province, near San Miguel (CMIOC-2329, 2334);

- Guatemala: El Prado, Izabal department (CMIOC-2312);

- Haiti: lake Miragoane (CMIOC-1571);

- Dominican Republic: Maguá river at Hato Mayor, El Seibo province (CMIOC-1566); San Cristóbal, San Cristóbal province (CMIOC-1567);

- Puerto Rico: Caguitas river at Caguas (CMIOC-1544);

- Barbados: Drax Hall, St. George parish (CMIOC-1483, 1484); Kendel, St. John parish (CMIOC-1488).

\section{ACKNOWLEDGMENTS}

This paper is based on specimens collected during two trips supported by the Pan American Health Organization. Thanks for the loan of the types of Planorbis helophilus and P. stagnicola are due to Mr Fred Naggs of the Department of Zoology, The Natural History Museum, London.

\section{REFERENCES}

Adams CB 1845. Specierum novarum conchyliorum, in Jamaica repertorum, synopsis. Proc Boston Soc Nat Hist 2: 1-17.

Adams CB 1851. Descriptions of new species and varieties of shells, which inhabit Jamaica. Contrib Conchol 8: 129-140.

Aguayo CG 1938. Los moluscos fluviátiles cubanos. Parte I. Generalidades. Mem Soc Cubana Hist Nat 12: 203-242.

Aguayo CG 1961. Aspecto general de la fauna malacológica puertorriqueña. Caribbean J Sci 1: 89105.

Baker FC 1945. The molluscan family Planorbidae. Univ Illinois Press, Urbana xxxvi +530 pp.

Clessin S 1884. Die Familie der Limnaeiden enthaltend die Genera Planorbis, Limnaeus, Physa und Amphipeplea. In Martini \& Chemnitz, Systematisches Conchylien-Cabinet , Ed 2, Bauer \& Raspe, Nürnberg.

Fischer P, Crosse H 1880. Études sur les mollusques terrestres et fluviatiles du Mexique et du Guatemala. In Mission Scientifique au Mexique et dans l'Amérique Centrale 2: 1-731.

Gould AA 1844. Descriptions and notices of some of the land shells of Cuba. Boston J Nat Hist 4: 485498.

Morelet A 1849. Testacea novissima insulae Cubanae et Americae centralis. Pars I. JB Baillière, Paris, 31 pp.

Morelet A 1851. Testacea novissima insulae Cubanae et America Centralis. Pars II. JB Baillière, Paris, 26 pp.

Orbigny A 1835. Synopsis terrestrium et fluviatilium molluscorum, in suo per Americam Meridionalem itinere collectorum. Mag Zool 5, Classe 5: 1-44.

Orbigny A 1837. Mollusques. In Voyage dans l'Amérique méridionale. Tome $5^{\mathrm{e}}, 3^{\mathrm{e}}$ Partie, Genre Planorbe : 342-352. P Bertrand, Paris.

Paraense WL 1957. Apertural lamellae in Australorbis glabratus . Proc Malacol Soc London 32: 175-179.

Paraense WL, Deslandes N 1956. Observations on Australorbis janeirensis (Clessin, 1884). Rev Brasil Biol 16: 81-102.

Paraense WL, Deslandes N 1962. Australorbis albicans (Planorbidae). Nautilus 75: 156-161.

Paraense WL, Ibañez N 1964. Australorbis helophilus (Pulmonata, Planorbidae). Rev Brasil Biol 24: 249258.

Pfeiffer L 1839. Bericht über die Ergebnisse meiner Reise nach Cuba im Winter 1838-1839. Arch Naturgesch 5: 346-358.

Richards CS 1963. Infectivity of Schistosoma mansoni for Puerto Rican mollusks, including a new potential intermediate host. Am J Trop Med Hyg 12: 2633.

Yong M, Hubendick B, Rodriguez J, Perera G 1984. Biomphalaria schrammi in Cuba. Walkerana 2: 141144. 